\title{
Enhancing Seed Health for Organic Vegetable Production Systems: Challenges and Opportunities
}

\author{
Leopold M. Nyochembeng ${ }^{1}$ \\ ${ }^{1}$ Department of Biological and Environmental Sciences, Alabama A\&M University, Normal, AL, USA \\ Correspondence: Leopold M. Nyochembeng, Department of Biological and Environmental Sciences, Alabama \\ A\&M University, Normal, AL 35762, USA. Tel: 1-256-372-4218. E-mail: leopold.nyochembeng@aamu.edu
}

Received: July 18, 2021

Accepted: October 10, $2021 \quad$ Online Published: November 15, 2021

doi:10.5539/jas.v13n12p35

URL: https://doi.org/10.5539/jas.v13n12p35

The research is financed by USDA-National Institute of Food and Agriculture Capacity Building Project 2020-38821-31100.

\begin{abstract}
Organic vegetable production is a rapidly expanding segment within the fast growing organic sector of agricultural production. Although pests and diseases remain a challenge in organic production, the growth and expansion of this system is dependent on sustained use of good quality organic seed. Due to the limited supply of organic seed, the National Organic Program (NOP) allows the use of untreated conventional seed in organic production of vegetables and other crops. Conventional seed derives from a high input production system using synthetic pesticides and fertilizers. They also offer many varieties and are readily available at a much lower price compared to organic seed. Organic systems demand cultivars with different characteristics often absent in conventional cultivars, and this need begins with the seed. It is not common practice for farmers to test or sanitize seed before planting. Consequently, the use of such conventional seeds, which may not be well adapted to the low input organic production system, could favor disease susceptibility, establishment of seedborne pathogens especially in vegetables and their subsequent dissemination in the organic production system. Our overall goal is to improve organic vegetable crop health and production in the southeastern U.S. through application of sustainable seed health management and help limit seed borne infections, transmission and dissemination in organic vegetable production fields.
\end{abstract}

Keywords: conventional seed, certified organic seed, seedborne disease, seed health

\section{Introduction}

Organic farming is currently the fastest growing agricultural sector worldwide with sales of organic products totaling $\$ 43$ billion in 2015 (Hubbard \& Zystro, 2016). However, plant diseases and weeds are among the major factors limiting its expansion (Nyochembeng et al., 2014). The United States Department of Agriculture (USDA)'s National Organic Program (NOP) defines organic as food produced without the use of conventional pesticides, petroleum-based fertilizers, sewage-sludge-based fertilizers, herbicides, pesticides, genetic engineering (biotechnology), antibiotics, growth hormones, or irradiation (NOP, 2000). In 2019, there were over 14,000 acres under certified organic vegetable production in southeastern US (USDA NASS, 2019) and this acreage continues to increase.

Most economically important organic vegetable crops produced in the southeastern US (tomato, cucumber, bell pepper, carrot, squash, watermelon, cabbage, lettuce, etc.) sexually propagate by seed. These crops are subject to attack and often infection by many seedborne and seed transmitted pathogens causing severe diseases (Table 1) and significant yield loss. An important requirement for successful organic farming is the use of seeds or other propagating plant material produced under organic farming conditions (Groot et al., 2004). This requirement is paramount to ensure crop adaptability to the production system and therefore crop performance and yield. Due to the restrictive nature of the organic production system, where there is no application of synthetic chemicals (fungicides, bactericides, etc.) seeds used in organic production may be predisposed to contamination with seed borne pathogens and weed seeds and have a high likelihood of harboring and disseminating plant pathogens. Although disease problems are adequately addressed in the system employing whole farm planning and 
integrated disease management (IDM) tools, it is more feasible under low acreages and does not easily translate to large acreages characteristic of conventional farming systems.

Currently, there is no policy put in place that safeguards the health and quality of seeds used in organic vegetable production systems. The Organic Seed Alliance (OSA) a non-governmental organization that advocates for robust organic seed industry, recommended that NOP amend its guidance document regarding organic seed by providing instructions to strengthen the consistent enforcement of the organic seed requirements and where necessary hold accountable farms that fail to comply with the policy or are not making continuous effort in improving their organic seed sourcing (Hubbard \& Zystro, 2016). The purpose of this study is to determine the relationship between the source of organic seed and the occurrence or incidence of seed borne and seed transmitted plant diseases in organic farms, and to identify challenges/constraints and opportunities to improve seed health quality and minimize the losses due to seedborne and seed transmitted diseases in organic vegetable production. Our overall goal is to improve organic vegetable crop health and production in the southeastern U.S. Through the application of sustainable seed health management, it is feasible to limit or eliminate seed borne infections in organic vegetable production fields.

\section{Challenges}

\subsection{Current Status of Seeds in Organic Vegetable Production}

It is generally accepted in the organic community that seeds used in organic production systems be produced organically. The mandatory use of organic seeds in organic production is one of the National Organic Program (NOP) standards of the USDA established in 2002. However, organic farmers face some challenges that restrict organic seed sourcing. Several surveys conducted between 2009 and 2015 (Hubbard \& Zystro, 2016) indicated that organic plant breeding is still in its infancy. Consequently, the supply of new organic seed varieties or preferred older varieties improved for organic production system is limited. Stakeholders have articulated the reasons why many farmers still use conventional seed in organic production. These include 1) organic certifiers exercise much leniency in the organic seed requirement as part of their regulatory enforcement and compliance, 2) specific varieties are not available in an organic form, 3) the overall supply of organic seed is not enough to meet the growing demand in the rapidly expanding organic farming industry.

\subsubsection{Use of Conventionally Produced Seeds by Organic Farmers (Lammerts van Bueren, 2003)}

Ideally, seeds used in organic production should be developed through new plant breeding for characteristic traits that are adapted to organic production conditions. Although organic plant breeding is ongoing, its progress is relatively slow due to many constraints. These include cost, limited funding in the public sector, overdependence on the public sector for funding, lack of incentives in the private sector to invest in organic seed breeding, lack of expertise, lack of experimental land resources, potential legal issues with intellectual property rights, and reluctance in regulatory enforcement of organic seed requirements by lenient certifiers. Due to the limited supply or lack of this new organic seed, which also increases cost, organic farmers are constrained to using untreated conventional seed as a substitute. Some farmers also use conventional seeds because of the superior quality attributes of the specific variety which is popular in the market place. It is therefore unlikely that the use of conventional seeds in organic production system will cease anytime soon despite existing regulations. There are also increasing numbers of new entrants into organic production who have to transition a minimum of three years before becoming certified and being subject to certification requirements. A significant segment of this group uses conventional seed varieties. Unfortunately, the vast majority of commercial conventional seed is bred to rely on high fertilizer and pesticide inputs. This can be seriously problematic for organic systems which rely on biopesticides and slow release of nutrients from organic soil amendments.

\subsubsection{General Lack of Knowledge/Concern for Seedborne Pathogens by Organic Growers}

Most organic farmers who use conventional seeds for vegetable production often obtain untreated seeds from vendors or use their own saved seed. Untreated seeds generally are seeds that are not coated with a fungicide or other synthetic seed protectant and therefore are likely to harbor seed borne pathogens that could be spread after planting the seed in the new field. One of the major opportunities identified by researchers in organic seed development is addressing seed-borne diseases (Hubbard \& Zystro, 2016). In southeastern US, seedborne pathogens causing failure of seedling establishment in vegetable crops are common. The spread of these pathogens is rapid through factors such as high relative humidity, populations of susceptible plants, high temperatures, and overhead irrigation (Walcott et al., 2003). The most effective management strategy under these conditions will be through pathogen exclusion, accompanied by using their specific detection assays to assess seed lots prior to planting the seeds. Seed assays must be sensitive, specific, rapid, robust and cost-effective. Seed assays that have been developed over the years involve visual examination, use of selective media, applications involving seedling 
grow-out methodologies, serology-based assays, and polymerase chain reaction (PCR)-based assays (Walcott et al., 2003). Each of these methodologies comes with its challenges. Assays that are designed for specific pathogen detection must be validated using stringent tests for evaluation of their reproducibility and repeatability.

\subsubsection{Lack of Accessible Indexing Tools to Rapidly Detect Seedborne Pathogens}

Several invaluable seed detection assays exist with rated sensitivity/specificity ranging from low to very high based on the time for assay completion, sensitivity, ease of application, specificity and applicability for detection of fungi, bacteria and viruses (Walcott, 2003). Of these assays, visual examination, semi-selective media, seedling grow-out and serology-based detection are the only simple, inexpensive methods that a grower can afford to perform. The most rapid and sensitive of these techniques is serology and currently there are commercial kits available for in situ detection of pathogens. Most organic growers do not yet employ these diagnostic tools and therefore detection of seedborne pathogens in organic production systems is not routine. In order to succeed in applying these tools, organic growers would need to seek the services of university plant clinics or the local/state extension plant disease diagnostic laboratory.

\subsection{Problems Associated With Conventionally Produced Seeds Used for Organic Production}

\subsubsection{Seed Health}

Conventional seeds are produced in a system that relies heavily on the use of pesticides and synthetic fertilizers over a prolonged season. If such seeds should harbor seedborne and seed transmitted pathogens and are used in organic production systems where minimal inputs are applied, they may transmit and disseminate plant diseases which management may be a serious challenge especially during the transition period (van Bruggen \& Termorskuizen, 2003). Currently, most organic producers do not practice or perform any type of seed health testing prior to planting their seeds. Crops grown from conventional seeds therefore need to be closely monitored for seed transmitted diseases to avoid or minimize their dissemination that could result in epidemics or depressed yields long-term. The current extension system is not fully equipped to serve the organic producers and assist in disease monitoring in organic fields.

\subsubsection{Seed Quality}

This refers to the state of viable seed devoid of infection or infestation with pathogenic organisms and other pests capable of maximizing potential crop productivity and value. Organic seed certification is adopted by some growers to ensure good quality "clean" seed is planted in their organic farm. It is interesting to note that a great majority of certified organic farmers are concerned about genetic contamination of their seed in organic fields (Sripathy et al., 2012). Plant pathogen contamination should also be an important consideration. Only a few organic growers take measures to prevent introduction of seedborne pathogens in their fields by carrying out seed testing, quarantine and indexing techniques probably because the ecological nature of the production system helps to minimize disease outbreaks (van Bruggen \& Termorskuizen, 2003). The vast majority relies on the seed suppliers to provide "clean" seed often with no interest in their seed borne disease status. Due to economics and current environmental awareness, more research effort needs to be directed toward biological seed treatments with further development and application of advanced DNA amplification technologies to enhance the detection of seedborne pathogens that otherwise will go undetected using conventional seed health testing methods (Sousa et al., 2015, 2016).

\subsubsection{Adaptability to the Organic Production System (Heirloom vs Hybrids)}

Heirloom vegetables are unique varieties that have been preserved by handing down seed from generation to generation. These varieties are generally 50 to 100 years old, although some are much older. All heirlooms are open-pollinated and usually breed true-to-type. Unlike hybrids, which have been bred for uniformity in size, shape, and ripening, including durability in shipping, heirlooms were often selected for flavor potential and eating quality (Kaiser \& Ernst, 2013). Many organic growers plant heirloom vegetables most of which are not resistant to current diseases and may be good targets for seedborne pathogens if not well managed. On the other hand, most hybrids have better disease resistance in addition to other desired quality traits.

\subsection{Seed Production Using Organic Production Systems}

\subsubsection{Cost of Producing Organic Seed}

Many producers agree that conventional seed is a lot cheaper to produce than organic seed. Consequently, it is also cheaper to buy. Organic seeds cost on average $65 \%$ more than conventional seed. Despite the high cost of organic seed, there is an increasing trend in the use of organic seed. A recent Organic Seed Alliance (OSA) report describes an increase in the number of farmers who use $100 \%$ organic seed by $7-10 \%$ across all crop types 
(Hubbard \& Zystro, 2016). However, these numbers are still low considering the rapid growth of the organic sector in recent years. Hence, many organic growers continue to use conventional seed in their organic operations.

\subsubsection{Difficulties With Biennial Vegetable Crops}

Biennial vegetable crops are grown over two continuous growing seasons and therefore remain exposed to pests and diseases over a longer period than annual crops. If resistant varieties are unavailable, the risk of pathogen contamination and infection is higher due to the length of time it takes to produce seed in these crops. Some varieties of cole crops such as cabbage, cauliflower, etc, are susceptible to seedborne pathogens such as black rot caused by Xanthomonas campestris pv campestris (Xcc) (Pammel) and alternaria leaf spot caused by Alternaria $s p$. often with very severe foliar symptoms.

\section{Opportunities}

\subsection{Monitoring Seedborne Pathogens in Production Fields}

Although it is the responsibility of the seed supplier/company to ensure that the seed lot is screened for seedborne pathogens before sale, it is important for the organic grower to double check where necessary to avoid disseminating seedborne pathogens. Many growers often do not practice this procedure either due to lack of training, cost, or neglect (Maclintock, 2018). Some seeds including tuberous propagating material (e.g., 'seed potato') can contain seedborne diseases such as blackleg caused by Dickeya dianthicola (Dickey), which can go unnoticed until it is too late (Dufault, 2016). Some crop (e.g., specialty crops grown at a small scale) seeds may not yet have commercial seed health tests available for the particular crop due to limited research on their seedborne pathogens (eXtension, 2016). Even after the seeds are planted, routine monitoring through regular field scouting for early symptoms of disease development is warranted.

There are now commercially available simplified tools that can be used directly by growers and producers to identify pathogens. Such grower-friendly tools include immunoprinting kits and lateral flow devices (LFDs) for detection of selected plant pathogens (De Boer \& Lopez, 2012). An important characteristic of the grower-friendly tool is that it should be simple, robust, cost-effective and have a long shelf-life.

\subsubsection{Application of Robotics}

UAVs/Agricultural drones for monitoring crop stress. Unmanned area vehicles (UAVs) equipped with special infra-red cameras are currently being deployed to facilitate the monitoring and detection of physiological stress in plants across a field. These technologies can be beneficially exploited in detecting plant diseases early leading to prompt interventions, and thus facilitating the prevention of disease spread in the production field.

\subsection{Development of New Seed Sanitization and Pathogen Monitoring Systems}

Currently, there are limited options for conducting seed sanitization for organic seeds. The most common is thermal treatment with hot water, which primarily targets seedborne bacterial pathogens and may not be effective against some bacterial pathogens such as Clavibacter michiganensis (Smith) subsp. michiganensis cause of bacterial canker in tomato (de Leon et al., 2011). There is need to develop new tools to aid in pathogen detection in organic systems including additional pathogen-specific antibodies and/or primers to address the many pathogens for which tools are not currently available, quantitative and multiplex forms of LFDs, biosensor technologies and mass spectrometric methods (De Boer \& Lopez, 2012). New seed sanitization techniques such as application of low temperature plasma which uses ionized air gases are being explored (Thirumdas, 2018; Jiang et al., 2014). Low temperature plasma treatment of rice seeds for $76 \mathrm{~s}$ led to a $90 \%$ level control against Gibberella fujikuroi (Sawada) the cause of bakanae disease (Jo et al., 2014; Spadaro et al., 2017). 
Table 1. Major seed-borne pathogens and seed transmitted diseases of important vegetable crops in southeastern US

\begin{tabular}{|c|c|c|c|c|}
\hline Pathogen & Disease Common Name & Hosts & Cultural Treatment Practices & References \\
\hline \multicolumn{5}{|l|}{ Bacteria } \\
\hline Acidovorax avenae subsp. citrulli & Bacterial fruit blotch & Cucurbitaceae & Use pathogen-free seed and transplants & Walcott, 2005 \\
\hline $\begin{array}{l}\text { Clavibacter michiganensis } \\
\text { subsp. michiganensis }\end{array}$ & Bacterial canker & Tomato & $\begin{array}{l}\text { Deep ploughing to bury infected crop residue, } \\
\text { practice } 2 \text {-year crop rotation, seed treatment }\end{array}$ & Gleason et al., 1991 \\
\hline Pseudomonas syringae pv phaseolicola & & Beans & Use of pathogen-free seed. & \\
\hline Pseudomonas syringae pv tomato & & Tomato & $\begin{array}{l}\text { Delay planting in spring to avoid } \\
\text { cool wet conditions, minimize } \\
\text { overhead irrigation, crop rotation. }\end{array}$ & Sun et al., 2017 \\
\hline Xanthomonas axonopodis pv phaseoli & Bacterial speck & Beans & $\begin{array}{l}\text { Use of pathogen-free seed, heat treatment, } \\
\text { resistant varieties. }\end{array}$ & Lo Cantore et al., 2015 \\
\hline Xanthomonas campestris pv campestris & Black rot & Brassica & $\begin{array}{l}\text { Sanitation, crop rotation, weed control } \\
\text { and use of assayed clean seed. }\end{array}$ & Vincente \& Holub, 2012 \\
\hline Xanthomonas campestris pv vesicatoria & Bacterial spot & Tomato, pepper & $\begin{array}{l}\text { Sanitation, use of pathogen-free seed, } \\
\text { resistant cultivars. }\end{array}$ & Hoda et al., 2005 \\
\hline \multicolumn{5}{|l|}{ Fungi } \\
\hline Alternaria dauci & Leaf blight $\&$ black rot & Umbelliferae & $\begin{array}{l}\text { Integrated use of clean seed, sanitation, } \\
\text { crop rotation, cultivar selection. }\end{array}$ & Farrar et al., 2004 \\
\hline Alternaria brassicae & Dark leaf spot & Cabbage & Hot water seed treatment, crop rotation. & Humpherson-Jones, 1989 \\
\hline Ascochyta pisi & Pea blight & Peas & Crop rotation. & \\
\hline Colletotrichum lindemuthianum & Anthracnose & Beans & $\begin{array}{l}\text { Use disease-free seed, crop rotation, } \\
\text { plough crop debris deep under, avoid } \\
\text { sprinkler irrigation, resistant varieties. }\end{array}$ & Liu et al., 2016 \\
\hline Colletotrichum acutatum & & Bell pepper & Disease-free seed, crop rotation (6-15 years). & Frate et al., 2017 \\
\hline Verticilium dahlia & Verticillium wilt & Spinach & Crop rotation with non hosts & du Toit et al., 2005 \\
\hline \multicolumn{5}{|l|}{ Viruses } \\
\hline Lettuce mosaic virus & Lettuce mosaic & Lettuce & Use virus-indexed seed, manage aphids & \\
\hline Pepino mosaic virus & Pepino mosaic & Tomato & $\begin{array}{l}\text { Use diseases-free seed, sanitation, } \\
\text { control insect vector (bumble bees). }\end{array}$ & Hansen \& Thomma, 2010 \\
\hline
\end{tabular}

\subsection{Organic Seed Treatment}

Seed quality is vital in seedling establishment, crop growth and production (Hopkinson \& Bishnoi, 2011). The use of seed treatment and more reliable seed health testing tools is critical to ensure seed health quality standards and for achieving phytosanitary requirements in the new millennium (Nameth, 1998).

The management and control of seed transmitted diseases in important organic vegetable cropping systems have been undertaken. Various tactics of biological control with antagonistic bacteria (Amkraz et al., 2010), composts (Yogev et al., 2009), plant activators for induction of resistance (Bishnoi et al., 2004; Soylu et al., 2003; Werner et al., 2002), plant essential oils (Daferera et al., 2003) or vegetable extracts (Balestra et al., 2009) and soil solarization have been used for managing bacterial canker in tomato (de Leon et al., 2011). The table below (Table 2) summarizes some of the broad-based techniques of seed treatment that are applicable to organic seed quality improvement in vegetable production systems. 
Table 2. Advantages and disadvantages of some methods of seed treatment used in organic vegetable production

\begin{tabular}{|c|c|c|}
\hline Method & Use/Advantage & Disadvantage/Deficiency \\
\hline Priming & Faster and uniform germination, earlier seedling establishment & No protection from attack by pathogenic microorganisms \\
\hline Pelleting & $\begin{array}{l}\text { Streamline size, shape and enhance uniformity in small non } \\
\text { round seeds (lettuce, onion, carrot etc.) }\end{array}$ & Some current pelleting materials not approved for organic use \\
\hline Hot water treatment & Eradicate seedborne bacterial pathogens & $\begin{array}{l}\text { Not effective against a broad range of seedborne pathogens; } \\
\text { Care and precision needed to protect embryo from damage; } \\
\text { works only for some seeds; seeds may lose vigor if stored } \\
\text { beyond the season. }\end{array}$ \\
\hline Plant extracts and oil & $\begin{array}{l}\text { Some plant extracts (thyme, oregano, garlic, hedychium, etc) } \\
\text { have shown promise as organic seed treatments and currently } \\
\text { in use in some European countries. }\end{array}$ & $\begin{array}{l}\text { Little data available in this area. Product may not have durable } \\
\text { protection in an exposed application. }\end{array}$ \\
\hline Biologicals & $\begin{array}{l}\text { Several microbial based products (Streptomyces lydicus, } \\
\text { Trichoderma, Gliocladium, Bacillus) are available } \\
\text { commercially for plant protection in organic system. }\end{array}$ & $\begin{array}{l}\text { Similar to plant extracts, tests with these organisms have } \\
\text { yielded inconsistent results probably due to method of delivery } \\
\text { to seeds. }\end{array}$ \\
\hline
\end{tabular}

Source: Organic Seed Resource Guide, E.W. Gatch, Washington State University.

However, serious challenges remain for managing many seedborne and seed transmitted devastating vegetable diseases due to lack of effective pathogen detection methods and seed treatment. Recent research developments in seed pathology technology (PCR, qPCR, real-time PCR and multiplex PCR) have provided sensitive tools and the opportunity to detect with high efficiency, many seedborne pathogens of vegetable crops.

\section{Conclusion}

In conclusion, it is apparent that although there is continued progress in breeding organic seed for organic crop production systems, some organic producers still use conventional untreated seed due to either cost or lack of availability of organic seed. Consequently, steps need to be undertaken to minimize or prevent the transmission and dissemination of seed-borne diseases associated with the conventional production systems from taking a foot hold in a low input sustainable production system of organic vegetable production.

\section{References}

Amkraz, N., Boudyach, E. H., Boubaker, H., Bouizgarne, B., \& Ben Aoumar, A. A. (2010). Screening for fluorescent pseudomonads, isolated from the rhizosphere of tomato, for antagonistic activity toward Clavibacter michiganensis subsp. michiganensis. World J. Microbiol. and Biotechnol., 26, 1059-1065. https://doi.org/10.1007/s11274-009-0270-5

Balestra, G. M., Heydari, A., Ceccarelli, D., Ovidi, E., \& Quattrucci, A. (2009). Antibacterial effect of Allium sativum and Ficus carica extracts on tomato bacterial pathogens. Crop Protection, 28, 807-811. https://doi.org/10.1016/j.cropro.2009.06.004

Bishnoi, U. R., Payyavula, R. S., \& Kumar, S. (2004). Enhancing disease resistance and yield in tomato and canola with plant activators. Research on Crops, 5, 268-273.

Daferera, D. J., Ziogas, B. N., \& Polissiou, M. G. (2003). The effectiveness of plant essential oils on the growth of Botrytis cinerea, Fusarium sp and Clavibacter michiganensis subsp. michiganensis. Crop Protection, 22, 39-44. https://doi.org/10.1016/S0261-2194(02)00095-9

De Boer, S. H., \& Lopez, M. M. (2012). New grower-friendly methods for plant pathogen monitoring. Annual Review of Phytopathology, 50, 197-218. https://doi.org/10.1146/annurev-phyto-081211-172942

De Leon, L., Siverio, F., Lopez, M. M., \& Rodriguez, A. (2011). Clavibacter michiganensis subsp. michiganensis, a seedborne tomato pathogen: Healthy seeds are still the goal. Plant Disease, 95, 1328-1339. https://doi.org/10.1094/PDIS-02-11-0091

du Toit, L. J., \& Gatch, E. W. (2009). Increasing the capacity for spinach seed production in the United States by promoting soil suppression of Fusarium wilt (p. 7). The Western Front, October 2009, Western Integrated Pest Management Center.

du Toit, L. J., Derie, M. L., \& Hernandez-Perez, P. (2005). Verticillium wilt in spinach seed production. Plant Dis., 89, 4-11. https://doi.org/10.1094/PD-89-0004

Dufault, N. (2016). Potato disease management starts with monitoring your seed stock. IFAS Extension.

eXtension. (2016). Disease management in organic seed production. Organic Seed Resource Guide. 
Feng, C., Mansouri, S., Bluhm, B. H., du Toit, L. J., \& Correll, J. C. (2014). Multiplex real-time PCR assays for detection of four seedborne spinach pathogens. Journal of Applied Microbiology, 117, 472-484. https://doi.org/10.1111/jam.12541

Frate, C. A., Gepts, P. G., \& Long, R. F. (2017). University of California IPM Pest Management Guidelines: Dry Beans. UC ANR Publication 3446.

Groot, S. P. C., van der Wolf, J. M., Jalink, H., Langerak, C. J., \& van der Bulk, R. W. (2004). Challenges for production of high quality organic seeds. Seed Testing International, 127, 12-15.

Hanssen, I. M., \& Thomma, B. P. H. J. (2010). Pepino mosaic virus: A successful pathogen that rapidly evolved from emerging to endemic in tomato crops. Mol. Plant Pathol., 11(2), 179-189. https://doi.org/10.1111/ j.1364-3703.2009.00600.x

Hoda, H. E., Osman, M. E., \& Sorour, N. M. (2005). Biological control of bacterial spot of tomato caused by Xanthomonas campestris pv. vesicatoria by Rahnella aquatilis Microbiological Research, 160(4), 343-352. https://doi.org/10.1016/j.micres.2005.02.008

Hopkinson, S. R., \& Bishnoi, U. R. (2009). Seed quality response of winter canola to planting date, seeding and nitrogen rates. Int. J. Agric. Environ \& Biotech., 2, 161-165.

Hubbard, K., \& Zystro, J. (2016). State of Organic Seed 2016. Organic Seed Alliance.

Humpherson-Jones, F. M. (1989). Survival of Alternaria brassicae and Alternaria brassicicola on crop debris of oilseed rape and cabbage. Ann. Appl. Biol., 115, 45-50. https://doi.org/10.1111/j.1744-7348.1989.tb06810.x

Jiang, J., Lu, X. Y., Li, J., Li, L., He, X., Shao, H., \& Dong, Y. (2014). Effect of seed treatment by cold plasma on the resistance of tomato to Ralstonia solanacearum (bacterial wilt). PLoS ONE, 9(5), e97753. https://doi.org/10.1371/journal.pone.0097753

Jo, Y.-K., Cho, J., Tsai, T.-C., Staack, D., Kang, M.-H., Roh, J.-H., ... Gross, D. (2014). A non-thermal plasma seed treatment method for management of a seedborne fungal pathogen on rice seed. Crop Science, 54, 796-803. https://doi.org/10.2135/cropsci2013.05.0331

Kaiser, C., \& Ernst, M. (2013). Heirloom vegetables. Kentucky Cooperative Extension Service.

Lammerts van Bueren, E. T. (2003). Challenging new concepts and strategies for organic plant breeding and propagation. In Th. J. L. van Hintum, A. Lebeda, D. Pink, \& J. W. Schut (Eds.), Eucarpia Leafy Vegetables 2003.

Liu, N., Xu, S., Yao, X., Zhang, G., Mao, W., Hu, Q., ... Gong, Y. (2016). Studies on the control of Ascochyta blight in field peas (Pisum sativum L.) caused by Ascochyta pinodes in Zhejiang Province, China. Frontiers of Microbiology, 7, 481. https://doi.org/10.3389/fmicb.2016.00481

Lo Cantore, P., Giorgio, A., Campion, B., \& Iacobellis, N. S. (2015). Development of integrated disease control measures for the valorisation of traditional crops in Southern Italy: The Case Study of Fagioli di Sarconi. In A. Vastola (Ed.), The Sustainability of Agro-Food and Natural Resource Systems in the Mediterranean Basin (pp. 145-158). Springer, Cham. https://doi.org/10.1007/978-3-319-16357-4_10

Lovic, B. R., \& Hopkins, D. L. (2003). Production steps to reduce seed contamination by pathogens of cucurbits. HortTechnology, 13, 50-54. https://doi.org/10.21273/HORTTECH.13.1.0050

Maclintock, M. (2018). Personal communication.

Nameth, S. T. (1998). Priorities in seed pathology research. Scientia Agricola, 55, 94-97. https://doi.org/ $10.1590 / \mathrm{S} 0103-90161998000500017$

National Organic Program. (2000). Rules and Regulations. Federal Register, 65, 246.

Nyochembeng, L. M., Mankolo, R. N., Mentreddy, S. R., \& Mayalagu, G. (2014). Cover crop, reflective polyethylene mulch and biofungicide effects on yield and management of field-grown organic tomato. $J$. Agric. Sci., 6(12), 265-275. https://doi.org/10.5539/jas.v6n12p265

Sousa, M. V., Machado, J. C., Simmons, H. E., \& Munkvold, G. P. (2015). Real-time quantitative PCR assays for the rapid detection and quantification of Fusarium oxysporum f. sp. phaseoli in Phaseolus vulgaris (common bean) seeds. Plant Pathology, 64, 478-488. https://doi.org/10.1111/ppa.12257

Sousa, M. V., Siqueira, C. S., \& Machado, J. C. (2016). Conventional PCR for detection of Corynespora crassiicola in soybean seeds. $J$. Seed Science, 38, 85-91. https://doi.org/10.1590/2317-1545v38n2152049 
Soylu, S., Baysal, O., \& Soylu, E. M. (2003). Induction of disease resistance by the plant activator, acbenzolar-S-methyl (ASM), against bacterial canker (Clavibacter michiganensis subsp. michiganensis) in tomato seedlings. Plant Science, 165, 1069-1075. https://doi.org/10.1016/S0168-9452(03)00302-9

Spadaro, D., Herforth-Rahme, D., \& van der Wolf, J. (2017). Organic seed treatments of vegetables to prevent seedborne diseases. In G. B. Oztekin \& Y. Tuzel (Eds.), ISHS Acta Horticulturae 1164: III International Symposium on Organic Greenhouse Horticulture (pp. 23-31). International Society for Horticultural Science. https://doi.org/10.17660/ActaHortic.2017.1164.3

Sripathy, K. V., Hosamani, J., Bellundagi, A., \& Prabhakar, I. (2012). Organic seed production. Environment \& Ecology, 30(1), 102-105.

Taylor, G., Gossett, Z., Williams, A., Nyaku, S., Lawrence, K., Sharma, G., \& Sripathi, V. (2018). Towards Understanding the Parasitic Nature of the Reniform Nematode using Microbiome and Metagenome Analyses. Plant \& Animal Genome Conference XXVI, January 13-17, 2018, San Diego, CA.

Thirumdas, R. (2018). Exploitation of cold plasma technology for enhancement of seed germination. Agricultural Research and Technology, 13(2), 555874. https://doi.org/10.19080/ARTOAJ.2018.13.555874

USDA NASS (U.S. Department of Agriculture's National Agricultural Statistics Service). (2019). Organic survey (Vol. 3, p. 550).

van Bruggen, A. H. C., \& Termorskuizen, A. J. (2003). Integrated approaches to root disease management in organic farming systems. Australasian Plant Pathology, 32, 141-156. https://doi.org/10.1071/AP03029

Vincente, J. G., \& Holub, E. B. (2013). Xanthomonas campestris pv. campestris (cause of black rot of crucifers) in the genomic era is still a worldwide threat to brassica crops. Molecular Plant Pathology, 14(1), 2-18. https://doi.org/10.1111/j.1364-3703.2012.00833.x

Walcott, R. R. (2003). Detection of seedborne pathogens. HortTechnology, 13, 40-47. https://doi.org/10.21273/ HORTTECH.13.1.0040

Werner, N. A., Fulbright, D. W., Podolsky, R., Bell, R., \& Hausbeck, M. K. (2003). Limiting populations and spread of Clavibacter michiganensis subsp. michiganensis on seedling tomatoes in the greenhouse. Plant Disease, 86, 535-542. https://doi.org/10.1094/PDIS.2002.86.5.535

Yogev, A., Raviv, M., Kritzman, G., Hadar, Y., Cohen, R., Kirshner, B., \& Katan, J. (2009). Suppression of bacterial canker of tomato by composts. Crop Protection, 28, 97-103. https://doi.org/10.1016/ j.cropro.2008.09.003

\section{Copyrights}

Copyright for this article is retained by the author(s), with first publication rights granted to the journal.

This is an open-access article distributed under the terms and conditions of the Creative Commons Attribution license (http://creativecommons.org/licenses/by/4.0/). 